\title{
コイに打る血液凝固と栓球の関連性
}

\author{
藤 方 明・池 田 弥 生
}

(1985 年 2 月 14 日受理)

\section{Relation between Blood Coagulation and Thrombocyte in Carp}

\author{
Akira FuJIKata* and Yayoi IKedA*
}

To investigate the mechanism that the blood coagulation time in stressed fish decreases below normal level, relation between blood coagulation and thrombocyte was studied in carp Cyprimus carpio (body weight: about $300 \mathrm{~g}$ ). Blood samples were collected from caudal vessels of unanesthetized fish with a syringe tipped with 20 -gauge needle.

One $\mathrm{m} l$ of the citrated blood was added with $0.1 \mathrm{~m} l$ of adrenaline $(1,10$ and $100 \mu \mathrm{M})$ or noradrenaline $(0.3,3.0$ and $30 \mu \mathrm{M})$ and incubated at $23^{\circ} \mathrm{C}$ for $10 \mathrm{~min}$. Ten and $100 \mu \mathrm{M}$ adrenaline decreased plasma recalcification time (PRT). Noradrenaline had less effect than adrenaline.

When $0.1 \mathrm{ml}$ of the $\alpha$-adrenergic receptor antagonist: phentolamine $(0.1,1.0,10$ and $100 \mu \mathrm{M})$ or the $\beta$-adrenergic receptor antagonist: propranolol $(0.1,1.0,10$ and $100 \mu \mathrm{M})$ were added to citrated blood before adding $10 \mu \mathrm{M}$ adrenaline, the effect of $10 \mu \mathrm{M}$ adrenaline was blocked by the phentolamine $(1.0,10$ and $100 \mu \mathrm{M})$ but not by the propranolol. Ten $\mu \mathrm{M}$ adrenaline was effective to decrease PRT on thrombocyte-rich plasma, but not on thrombocyte-poor plasma and blood samples from stressed fish.

PRT decreased with the increase of thrombocyte number. Prothrombin time was not affected by these catecholamines.

These results suggest that thrombocyte participates in the intrinsic blood coagulation with the increase of its number and blood catecholamine level, particularly adrenaline, in the blood of stressed fish reacting to the adrenergic $\alpha$-receptor.

哺乳類ではてドレナリンによって血小板が一次及び二 次凝集を起こし，その際，凝集した血小板から血葆中に 種々の凝固促進物筫が放出され，また血小板第 3 因子が 膜表面に露出, 活性化されることが広く認かられてい る。魚類でも高浱度のアドレナリンにより陉球が凝集を 起こすことやが知られており，更にストレス時には血中 のアドレナリン潭度の上䍙 ${ }^{2,3)}$ と栓球数の增加 ${ }^{4-7)}$ が起こ ることも報告されている。先に報告 らはコイに取り报いストレスを加关た時，血漿の凝固時 間が短縮することを爻ている。これらのことから，魚類 でも血中のカテニールアミンが栓球と反応し, 血液凝固 時間に影響を及ぼしていることが考えられる。

本啹では in vitroに执て，栓球とカテュールアミン との関保を模討した。

\section{材料及び方法}

供試魚には体重 $300 \mathrm{~g}$ 前後のコイ Cyprinus carpio を 用い，実験期間中の水温は $23 \sim 27^{\circ} \mathrm{C}$ の範国であった。 取り扱いストレスを最小限に㧕えるよら注意して，麻醉
せずに速やかに尾部血管から注射器を用いて採血し, 直 ちに血液㠜固防止剂として，3.8\% クェン酸ナトリウム 溶湤を血液 9 容に対して 1 容の割合で加えた。この血液 より得られた血等を陚料として奏施した㠜固検査は血楾 カルンウム再加時間 (PRTと略す)，プロトロンビン時 間 (PTと略す), 及び活性化部分トロンボブラスチン時

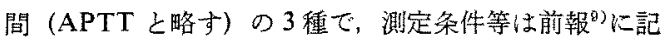
した通りである。検查した項目及び方法を次に述心゙る。

アドレナリン及びノルアドレナリンの影響 クエン酸 ナトリウム溶渡を加えた全血索均等飞 $1 \mathrm{ml}$ ずつ4本の シリコン処理を施した試験管に分け，1，10 及び $100 \mu \mathrm{M}$ のアドレナリン溶液を $0.1 \mathrm{ml}$ ずつ上記の試験管のらち の3本に加えた。残りの試験管には対照として淡水魚用 リンダル液 $0.1 \mathrm{ml}$ を加えた。ノルアドレナリンの場合 には全血を $1 \mathrm{ml}$ ずつ 5 本の試験管に分け，3本には $0.3,3$ 及び $30 \mu \mathrm{M}$ ノルアドレナリン溶液を $0.1 \mathrm{~m} l$ ず つ加之, 残りの2本にはリンゲル液と, $10 \mu \mathrm{M}$ アドレナ リン溶液をそれぞれ $0.1 \mathrm{ml}$ ずつ加えた。これらの試験 管を $23^{\circ} \mathrm{C}$ で 10 分間放置した後, $3,000 \mathrm{rpm}, 10$ 分間の

* 東京水産大学 (Tokyo University of Fisheries, 5-7, Konan 4, Minato, Tokyo 108, Japan). 
遠心分離により血墏を採取し，PRT，PT を湘定した。

ストレスの加わった供試魚より得られた試料に対する アトレナリンン添加の影響 供試魚を飼育槽 $(400 l)$ より $40 l$ 水槽汇移し, 2 分間網で軽く追い廻した後, 4 分間 休ませた。この供試魚より得られた血液を試料として先 と同梯な方法で $10 \mu \mathrm{M}$ アドレナリン溶液及びリンゲル 液を添加し，PRT，PT 及び APTTを測定した。

フェントラミン及びプロプラノロールの影響 クェン 酸ナトリウム溶液を加壳た全血を均等に 6 本の試験管に $1 \mathrm{ml}$ ずつ分け， 2 本にはりンダル液 $0.1 \mathrm{~m} l$ を加えた。 他の 4 本の試験管には $\alpha$ 遮断剤のフェントラミン, ある いは $\beta$ 遮断剂のプロプラノロールの $0.1 ， 1 ， 10$ 及び $100 \mu \mathrm{M}$ 溶液を $0.1 \mathrm{ml}$ ずつ加えた。次にこれらをそれぞ れ $25^{\circ} \mathrm{C}$ で1分間放置した後, 先にリンゲル液を添加し た 2 本の試験管のうちの 1 本にリンゲル液を $0.1 \mathrm{~m} l$ 更 に加之, 他の 5 本の試験管には全て $10 \mu \mathrm{M}$ フドレナリ ン溶液 $0.1 \mathrm{ml}$ を加えた。これらを $25^{\circ} \mathrm{C} て ゙ 10$ 分間放 置した後, 遠心分離を行い得られた血漿を試料として PRT 及び PT を測定した。

Thrombocyte-rich plasma におけるアトレレナリン添加 の影響 クエン酸ナトリウム溶液を加えた全血を 1,200 $\mathrm{rpm}, 5$ 分間遠心分離し血漿を得た。この中には未だ $1 \mu l$ 中約 1,100 個の血球が残されており，その多くは鏡 検により栓球であると推測された。この Thrombocyterich plasma (TRP と略す) を $1 \mathrm{~m} l$ ずつ 2 本の試験管 に分壮，一方にはりンゲル液，他方には $10 \mu \mathrm{M}$ アドレナ
リン溶液をそれぞれ $0.1 \mathrm{ml}$ ずつ加兄た。次にこれらを $25^{\circ} \mathrm{C}$ で 10 分間放置した後, 冷却遠心器により更に $10,000 \mathrm{rpm}, 10$ 分間遠心分離して栓球をむ含まない血獎 を作成し，PRT 及び RT を測定した。対照として，別 に $10,000 \mathrm{rpm}, 10$ 分間の遠心分離により栓球を含まな い血漿を採取し，TRP の代わりにこの血獎を用いて同 様な実験を行なった。

栓球数の影響 TRP を栓球を含まない血漿で希釈し， 栓球数を変えた時の PRT を測定した。

以上，いずれの実験に揖いてる $3 \sim 4$ 個体ずつ調べた。

なお，今回使用した薬品はアドレナリン（第一製菜 K.K.製)，ノルアドレナリン (三共K.K.製)，フェン トラミン：メシル酸フェントラミン(日本チバガイギー K. K、製)，プロプラノロール：塩酸プロプラノロール (住友化学工業 K.K. 製) であり, いずれも実験当日淡 水魚用リンゲル液で必要濃度に希飖し使用した。

\section{結果及び考察}

アドレナリン及びノルアドレナリンの影響 アドレナ リンを全血に添加した時の PRT, PT の変動を Fig. 1 に示した。PRTはリンゲル液を添加したAでは凝固時 間の平均が 34.0 秒であり, $1 \mu \mathrm{M}$ アドレナリン溶液を添 加したB と浪とんど差はないが, $10 \mu \mathrm{M}$ を添加したCで は 23.5 秒と短縮し，100 $\mu \mathrm{M}$ を添加した D るこれとほ ぼ同じ結果となった。PT はいずれも28 秒前後であり 特にアドレナリンの影響は見られなかった。次にノルア
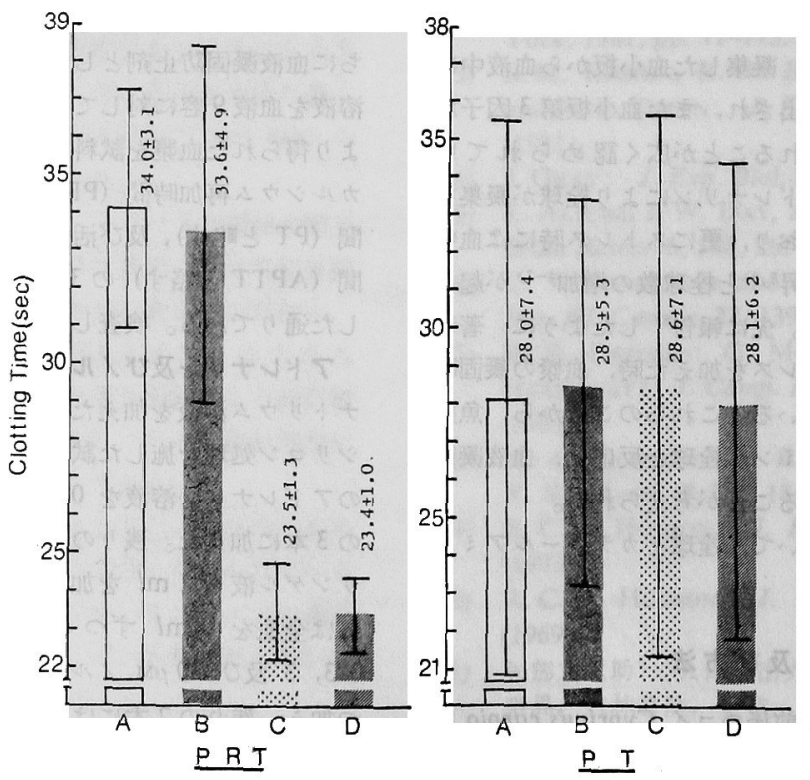

Fig. 1. Effect of adrenaline on plasma recalcification time (PRT) and prothrombin time (PT).

A: control, B: $1 \mu \mathrm{M}, \mathrm{C}: 10 \mu \mathrm{M}, \mathrm{D}: 100 \mu \mathrm{M}$. The values are mean $\pm \mathrm{SD}(\mathrm{n}=3)$. 

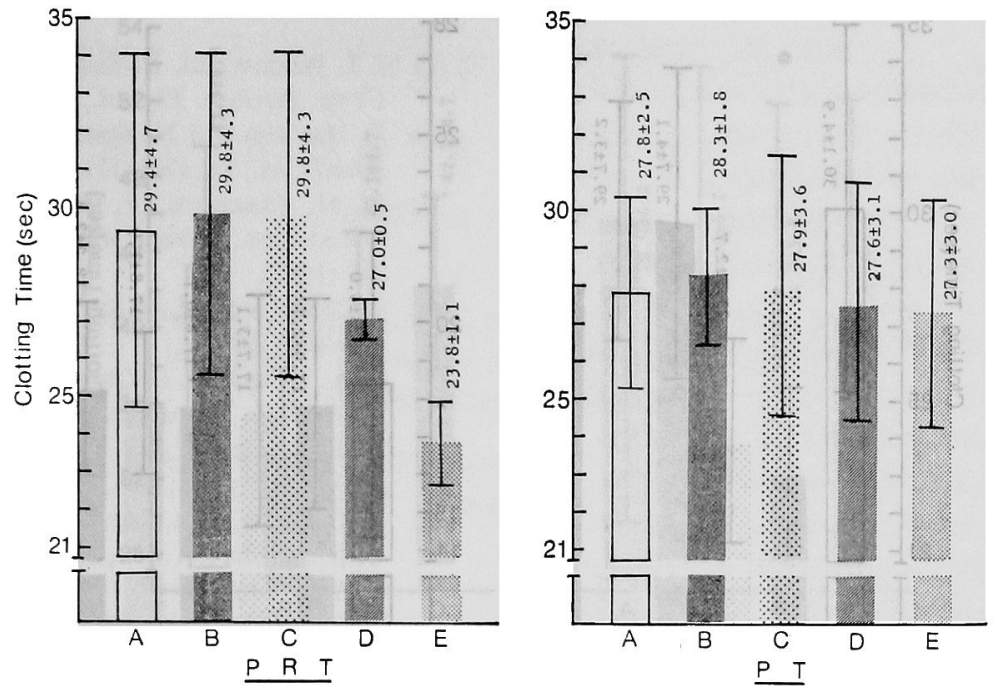

Fig. 2. Effect of noradrenaline on PRT and PT. A: control, B: $0.3 \mu \mathrm{M}, \mathrm{C}: 3.0 \mu \mathrm{M}, \mathrm{D}: 30 \mu \mathrm{M}, \mathrm{E}$ :

$10 \mu \mathrm{M}$ adrenaline. The values are mean $\pm \mathrm{SD}(\mathrm{n}=3)$.

ドレナリンによる影響 (Fig. 2) を PRT でみると, リ ンゲル液を添加した A と比較して，0.3 及び $3.0 \mu \mathrm{M} の$ ノルナドレナリンを添加した B，C ではその効果はほ とんど見られなかったが， $30 \mu \mathrm{M}$ の D ではわずかに短 縮した。しかし，その効果は10 $10 \mathrm{M}$ アドレナリンを添加 した E と比較すると，僅かであった。 PT にはノルアド レナリンの影響は見られなかった。以上の結果から PRT にはノルアドレナリンよりるアドレナリンの効果 の方が強く現われたが，その作用は血球の持つ受容体を 介して現われるものと推測される。よって次の実験を試 みた。

ストレスの加わった供試魚より得られた試料に対する アドレナリン添加の影響 結果を Table 1 に示した。 休息時における PRT はアドレナリン添加によってその 効果が見られるが，ストレスが加わっている場合には対 照区でも PRT が 17.0 秒, PT が 20.3 秒と低值を示 し，且つアドレナリンの効果は見られなかった。これら の結果より, ストレスの加わった供試魚で凝固時間が短 縮する理由として，ストレス下において増加したカテュ
ールアミン, 特にアドレナリンが血球の持つアドレナリ ン性 $\alpha$ あるいは $\beta$ 受容体を介してその作用を発現したこ とが推測される。この点を確かるる為, 次の実験を行っ た。

フェントラミン及びプロプラノロールの影響 フェン トラミンで前処理した時のアドレナリン添加効果をFig. 3 に示した。PRT はリンゲル液だけを添加した A では 30.1 秒であるが, $10 \mu \mathrm{M}$ アドレナリン溶液を添加した B では 23.1 秒に短縮しておりその効果がみられた。しか し，10 $\mu_{\mathrm{M}}$ アドレナリン溶液を加える前にフェントラ ン $0.1 \mu \mathrm{M}$ 溶液を加えた C ではわずかに，また $1.0 〜$ $100 \mu \mathrm{M}$ 溶液を加えた D, E, F ではその効果は見られな かった。PTはいずれも 18 秒前後で, その効果は見ら れなかった。次に同様な実験をプロプラノロールについ て行ないFig. 4 に示した。PRT は先之同様にBでア ドレナリン添加の効果が見られた。しかしプロプラノロ ールをアドレナリンを添加する前に加えた C, D, E, F に はその影響は見られなかった。また，PTについても 特に効果は見られなかった。以上より PRTにおいてア

Table 1. Effects of adrenaline on plasma clotting times of blood samples from stressed fish. The values are mean \pm S.D. $(n=3)$

\begin{tabular}{clccc}
\hline \hline Fish sample & \multicolumn{1}{c}{$\begin{array}{c}\text { Blood sample } \\
\text { treatment }\end{array}$} & $\begin{array}{c}\text { Plasma recalcification } \\
\text { time }(\mathrm{s})\end{array}$ & $\begin{array}{c}\text { Prothrombin time } \\
(\mathrm{s})\end{array}$ & $\begin{array}{c}\text { Activated partial } \\
\text { thromboplastin time } \\
(\mathrm{s})\end{array}$ \\
\hline Resting & Control & $34.0 \pm 3.1$ & $28.0 \pm 7.4$ & - \\
& Adrenalinized $(10 \mu \mathrm{M})$ & $23.5 \pm 1.3$ & $28.5 \pm 5.3$ & - \\
Stressed & Control & $17.0 \pm 4.0$ & $20.3 \pm 0.8$ & $9.3 \pm 1.3$ \\
& Adrenalinized $(10 \mu \mathrm{M})$ & $16.8 \pm 3.5$ & $20.8 \pm 0.9$ & $9.1 \pm 1.2$ \\
\hline
\end{tabular}



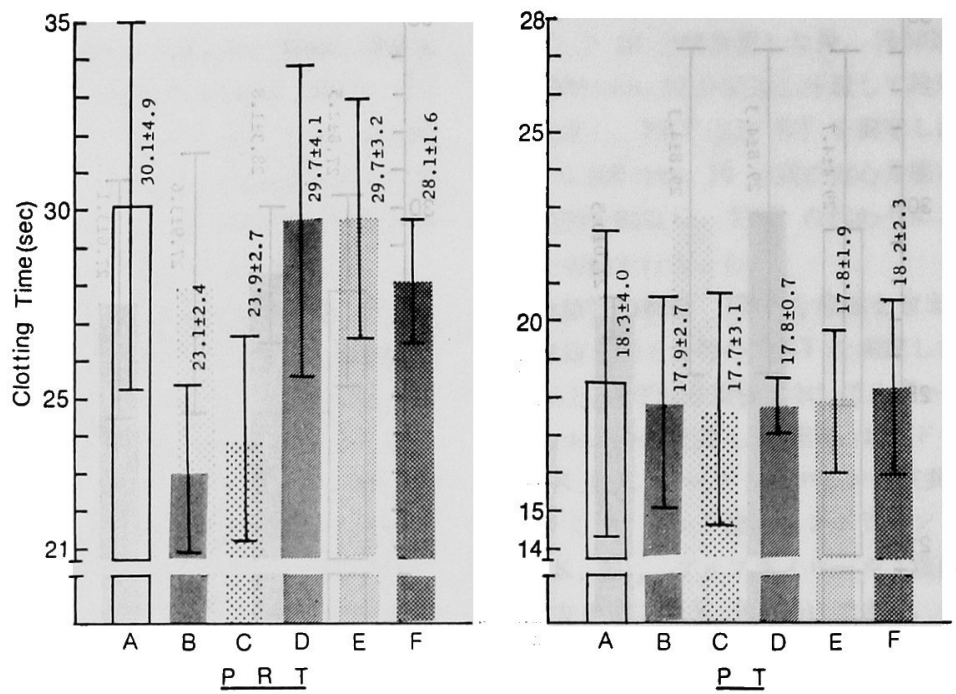

Fig. 3. Inhibition of the effects of adrenaline by phentolamine on PRT and PT. A: control, B: $10 \mu \mathrm{M}$ adrenaline, $\mathrm{C}, \mathrm{D}, \mathrm{E}$ and $\mathrm{F}$ : phentolamine $(0.1,1.0,10$ and $100 \mu \mathrm{M}$, respectively) plus $10 \mu$ M adrenaline. The values are mean \pm SD $(n=3)$.
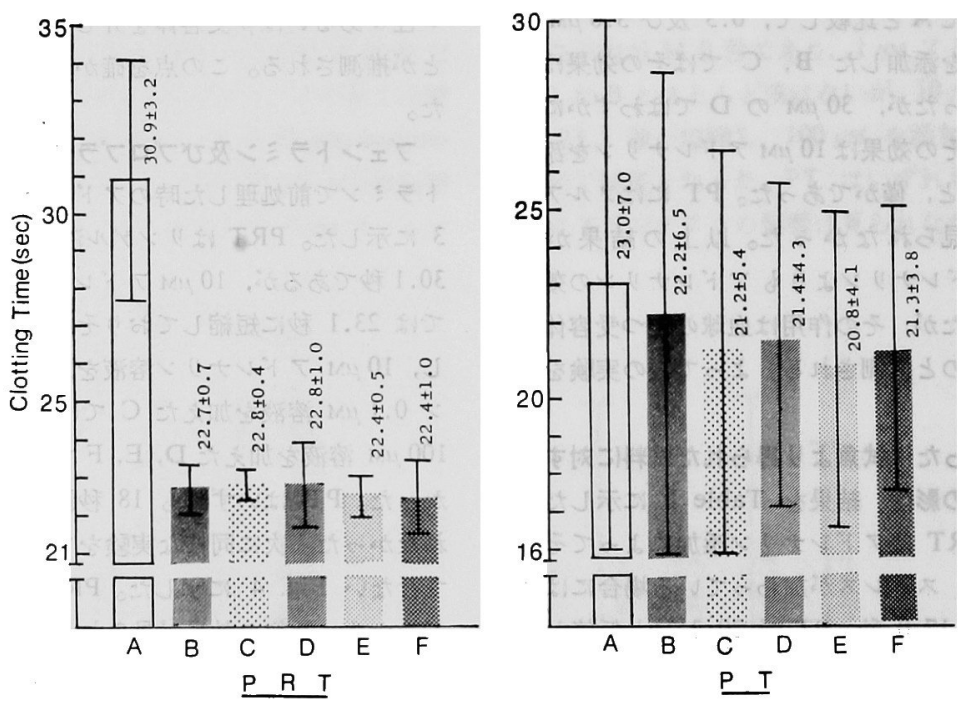

Fig. 4. Inhibition of the effects of adrenaline by propranolol on PRT and PT. A: control, B: $10 \mu \mathrm{M}$ adrenaline, C, D, E and F: proplanolol (0.1, 1.0, 10 and $100 \mu \mathrm{M}$, respectively) plus $10 \mu \mathrm{M}$ adrenaline. The values are mean $\pm \operatorname{SD}(\mathrm{n}=3)$.

ドレナリン添加の効果は $\alpha$ 遮断剂であるフェントラミン によって阻害され， $\beta$ 遮断剂であるプロプラノロールに よっては影響されないことから，血球のもつアドレナリ ン性 $\alpha$ 受容体を介して現れるものと考えられる。次に, アドレナリン効果が見られる血球が哺乳類の血小板に相 当する栓球であることを確認する為に, 次の実験を行っ た。
Thrombocyte-rich plasma におけるアトレナリン添加 の影響 結果を Fig. 5 に示した。PRT は通常の 3,000 $\mathrm{rpm}, 10$ 分間の遠心分離と比較して, $10,000 \mathrm{rpm}, 10$ 分間の遠心分離を行った為, いずれも延長した。しか し，TRPにリンゲル液を添加した A と比較して，10 $\mu \mathrm{M}$ アドレナリン溶液を添加した B では全血の場合と同様 に，アドレナリン添加の効果が見られた。これに対して 

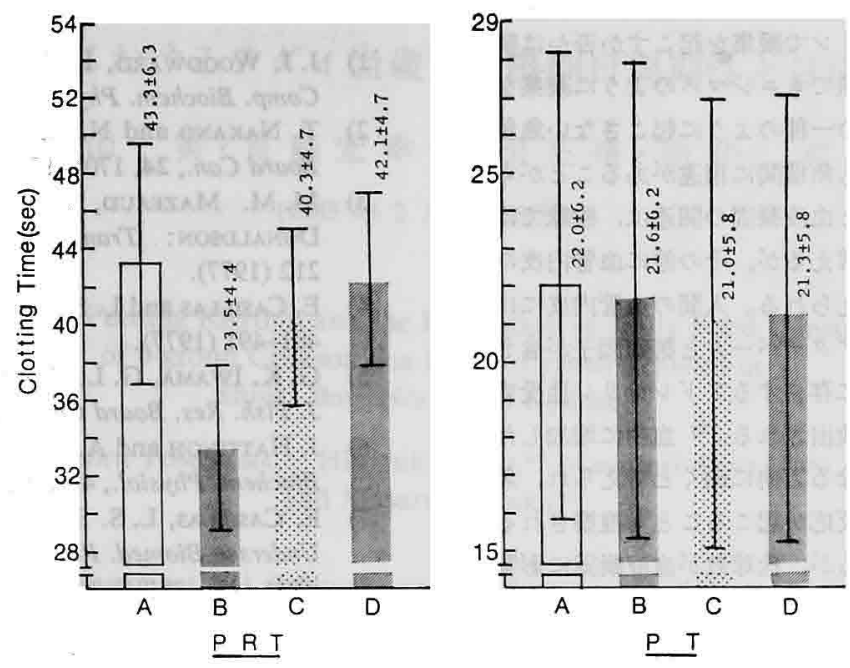

Fig. 5. Effect of adrenaline on PRT and PT of thrombocyte-rich plasma (TRP) and thrombocytepoor plasma (TPP). A: control on TRP, B: $10 \mu \mathrm{M}$ adrenaline on TRP, C: control on TPP, D: $10 \mu \mathrm{M}$ adrenaline on TPP. The values are mean $\pm \mathrm{SD}(\mathrm{n}=4)$.

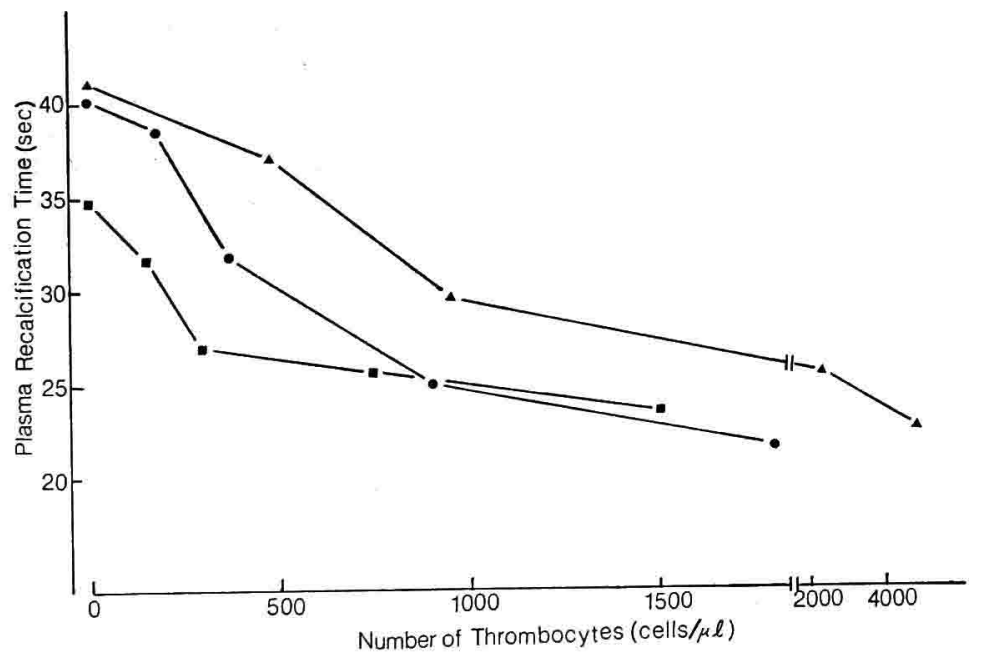

Fig. 6. Effect of number of thrombocytes on PRT. Each line with marks: $\bullet, \mathbf{a}, \mathbf{\Delta}$ in the figure indicates different samples.

栓球を含まない血漿にリンゲル液を添加した C と， $10 \mu \mathrm{M}$ アドレナリン溶液を添加した D を比較するとそ の効果は見られなかった。本実験では柽球とアドレナリ ンを反応させた後, 血墏中の栓球を除去している為, こ こで見られた PRT の短縮は柽球の放出反応によるもの と推測される。PT には特に差異は見られなかった。

栓球数の影響 血漿中の栓球数による PRTの 変動を

Fig. 6 に示した。いずれの個体においても栓球数の増加 と共に PRT は短縮した。PRT は遠心分離条件によっ
て影響を受けること日゙から本実験の結果もこれを裏付け るものと考えられる。

以上の結果から，魚類がストレスを受けた時に見られ る PRT の短縮原因として, 血中に増加したアドレナリ ンはアドレナリン性 $\alpha$ 受容体を介して栓球に作用し, そ の結果栓球から血中に凝固促進物質が放出される為と考 えられる。アドレナリンによる人間の血小板凝集は $\alpha$ 遮 断剤により完全に阻止されるが， $\beta$ 遮断剤では影響を受

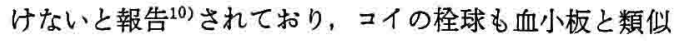


した機構を備えていると考えられる。しかし，コイの栓 球が高濃度のアドレナリンで疑集を起こすか否かは明ら かではなく，魚類の柽球でもニジスのように㠜集を起

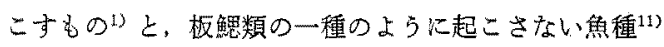

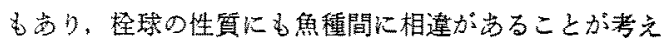
られる。フドレナリンと血液凝固の関連は，栓球では凝

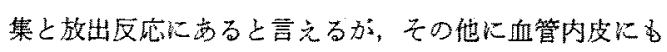
影響を及ぼすことが考えられる。人間の血管内皮には多 量のプラスミノーゲンアクキペータと第证因子が合まれ でり，これらは内皮に存在するアトレナリン性受容体 が刺激されると血中に放出される。祖中に增加した第 测因子は凝固を促進させる方向に働くと考えられ，魚類 においてもこの一連の反応が起こることも推察される。

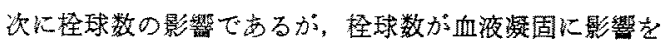
与えることは過去の報告(3，14)に加えて本实験からる明ら かである。問題となるのはストレス下に的ける㑠球数の 变動であるら。しかし，ての機権を説明した報告は見当 らなく，この点はりンパ球のストレスに対する反它含 めて包括的な検討が必要である。今回の契験ではストレ ス時のPTの哣縮は柽球との咸璉に扎いては説明できな かったが，栓球の凝集塊が血管内皮に傷害を与えること 推測される為, in vivo では間按的に栓球が PT 短縮 の原因となっていることも考えられ，さらに㛟討を必要 とする。
文

1) J. J. WoOdWARd, L. SMrTh, and E. CASIllas: Comp. Biochem. Physiol., 68A, 457-466 (1981).

2) T. Nakano and N. Tomlinson: J. Fish. Res. Board Can., 24, 1701-1715 (1967).

3) M. M. Mazeaud, F. Mazeaud, and E.M. Donaldon: Trans. Am. Fish. Soc., 106, 201212 (1977).

4) E. Casillas and L. S. SMith: J. Fish. Biol., 10, 481-491 (1977).

5) G. K. I wama, G. L. Green, and P. A. Larkin: J. Fish. Res. Board Can., 33, 285-289 (1976).

6) J. Hattingh and A. J. J. VAN Pletzen: Comp. Biochem. Physiol., 49A, 607-609 (1974).

7) E. Casillas, L. S. SMith, and B. G. D'Aoust: Undersea Biomed. Res., 3, 273-281 (1976).

8) 藤方 明 - 池田弥生: 日水誌, 51, 1093-1096 (1985).

9) 藤方 阴・池出弥生：日水耪， 51， 933-939 (1985).

10) D. C. B. Mills and G. C. K. Roberts: J. Physiol., 193, 443-453 (1967).

11) F. A. Belamarich., M. H. Fusari, D. Shepro, and M. KIEN: Nature, 212, 1579-1580 (1966).

12) M. Brozovic: Br. Med. Bull, 33, 231-238 (1977).

13) R. F. DOOLITtLe and D. M. SURgenor: $A m . J$. Physiol., 203, 964-970 (1962).

14) A. K. Srivastava: Anat. Anz. Bd., 124, 368374 (1969). 